\title{
Cultural Barriers: Pros and Cons on ELT in Iran
}

\author{
Dr. Mahinnaz Mirdehghan (Corresponding author) \\ Assistant Professor of Linguistics \\ Faculty of Letters \& Human Sciences, Shahid Beheshti University, G.C. \\ 1983963113, Tehran, Iran
}

Tel: 98-21-2990-2492 E-mail: M_Mirdehghan@sbu.ac.ir

\author{
Niloufar HoseiniKargar \\ B.A. in Urdu Language and Literature, Iran \\ E-mail: nilo0_15@yahoo.com \\ Somaye Navab \\ M.A. in Linguistics, Shahid Beheshti University, Iran \\ E-mail: Navab_so@yahoo.com \\ Tahere Mahmoodi \\ M.A. in Linguistics, Shahid Beheshti University, Iran \\ E-mail: t.mahmoodi2008@yahoo.com
}

\begin{abstract}
During the process of language learning some crucial cultural factors may be notified, seriously hindering the effective learning process, and commonly known as cultural barriers. Effective language learning among different cultures is especially challenging, due to the different ways of thinking, seeing, hearing, and interpreting the world provided by cultures. Cultural barriers are considered as those traditions which become hurdles in path of understanding or teaching/learning different languages, among which body language, religious beliefs, etiquette and social habits are noteworthy. The present study is mainly focused on the positive and negative impacts of cultural barriers on English language teaching/learning process in Iran. Accordingly, the effect of the usage of social factors, religious matters, taboo words as cultural dimensions are investigated, on the basis of the questionnaires prepared and distributed among 80 Shahid Beheshti University (Tehran/Iran) students. The questions are mainly to diagnose the cultural elements which might hinder or foster the learning process, and to propose solutions on its basis. The analysis describes the relationships between the items in the survey. For the purpose of the research percentages are used to express how the five main domains under consideration and the included matters are relative to one another. The statistical analysis of the questionnaires explores the effect of the usage of cultural dimensions on ELT in the community being studied. The partial effect of each domain is calculated, the results of which highlight the main criteria included under the broad term of cultural barriers and its implications on overcoming the desired outcomes in the teaching/learning process in Iran.
\end{abstract}

Keywords: Cultural barriers, ELT, Linguistic aspects, Taboo words

\section{Preface}

Culture is an integral part of every human's life. Each individual is born in a special cultural context which results in acquiring its different aspects in life. In general terms, culture may be defined as a set of social beliefs, values, religions, credence and ideologies accepted by most members in a social community.

During the process of language learning some crucial cultural factors may be notified, seriously hindering the effective learning process, and commonly known as cultural barriers. Effective language learning among different cultures is especially challenging, due to the different ways of thinking, seeing, hearing, and interpreting the world provided by cultures. Cultural barriers are considered as those traditions which become 
hurdles in path of understanding or teaching/learning different languages, among which body language, religious beliefs, etiquette and social habits are noteworthy.

English language education specifically for adults requires cultural awareness which can imply positive as well as negative impacts. The related literature (Byram 1989; Byram \& EsarteSarries 1991; Holliday 1984; Kress 1993; among others; cf. Riona 2007) illustrates the matter importance, together with its lack in English teaching in Iran. On the basis of the significance of English as an international language, spoken and taught worldwide, the present research focuses on the cultural impacts and barriers on ELT and effective communication in Iran. In accordance Alptek (1993: 137) asserts 'systemic' and 'schematic' knowledge as the types of expression and interpretation of meanings in languages; within which the former includes syntactic/semantic aspects and the latter social (cultural) matters. He further considers the existing 'fit' among people's culture-specific cognition and native language.

The survey data is organized on the basis of the questionnaires prepared and distributed among 80 Shahid Beheshti University students. The questions are mainly to diagnose the cultural elements which might hinder the learning process, and to propose solutions on its basis; for the purpose of which frequency tables of percentages are calculated and presented throughout the paper. The analysis describes the relationships between the items in the survey. Obviously, the selection of the variables included in the tabular analysis is based on the research findings.

\section{Review of literature}

Cultural awareness develops out of, and is parallel to, the awareness of the sociolinguistic dimension of language study. The relationship between language learning and cultural experience is mutually supportive (Byram and Esarte-Sarries 1991: 14). Adult foreign language education needs even more expertise in and concern for cultural awareness (Kniffka 2001). New technologies are beginning to show effects on our use of language, and may be expected to produce fundamental change. The increasing speed in interaction at a distance, e.g., fax, e-mail, may be considered as an important factor in accordance (Kress 1993: 2).

Researches show that motivation in L2 learning is also of great importance, either instrumental or inherent. Students learn English for different instrumental purposes such as knowing more about their field of study, showing of, migrating, jobs or for inherent purposes as their interest. Motivation has a direct relationship with the acceptance or resistance against the culture of the language which they taught (in this case English). For example a person who learns English language for his field of study may not closely entangle with English culture as much as the one who wants to learn it for showing of. So the role of motivation in transferring culture is of great very importance. Preferring a culture over the other can be as a sign of learners' society which they want to belong to. Gardner and Lambert $(1959,1972)$, show that learners' ethno-centric attitudes have a direct relationship to their success in learning the second language.

Cultural environmental differences give the second language learners a kind of social psychological distance (Huang, 2009). Therefore, social distance restricts the use of language and causes the fossilization of second language (Chen, 1999). According to Heller (1987) shared way of speaking and shared culture and knowledge enhances shared social identity, and a shared identity strengthens the social network of in-group members.

It has been accepted (Vorih and Rosier, 1978; Harris, 1982) that bilingual education can break down cultural barriers between community and school and produce a greater commitment by the community to the project of the school. It has also been argued that the incorporation of the culture of the minority group leads to greater cultural sensitivity on the part of the teacher (Folds, 1989).

Living in a culturally diverse world, requires encountering cultural barriers in learning languages of different races, religions, and nationalities, effectively. Knowing about these traditions, which may become hurdles in teaching/learning process, will help to achieve better results and to solve learners' problems in classrooms.

These barriers require research, due to the fact that people from different backgrounds may have varied approaches to the conflicts. Accordingly, the impossibility of knowing the varied systems of all cultures requires the process to be approached in one culture at a time as to meet and deal with a new one.

On the basis of the significance of English as an international language, spoken and taught worldwide, the present research focuses on the cultural impacts and barriers on ELT and effective communication in Iran. The present study is mainly focused on the positive and negative impacts of cultural barriers on English language teaching/learning process. Accordingly, the effect of the usage of social factors, religious matters, and taboo words as cultural dimensions are investigated throughout the research, in which culture interferes with effective cross-cultural English learning. The research question is to find out the effect of the usage and the common 
cultural barriers in Iran which mainly hinder English language learning, as well as exploring the percentage of each matter in the community being studied.

\section{Significance of the Study}

The significance of the study mainly lies in the teaching/learning process of English as an international language, spoken and taught worldwide as a foreign or second language. It is mainly focused on the cultural impacts and barriers on ELT and effective communication in Iran. This research need is mainly seen in its implications on achieving more effective English teaching/learning process in Iran and overcoming the shortcomings across Iranian and English cultures. Being aware of the potential for these problems will help the course designers to have a proactive approach to the requirements, and the learners to develop their skills and not to fall victim to them!

\section{Methodology}

The study is organized on the basis of analyzing the questionnaires that are prepared according to the methods for Inter-Language assessment (DCT) and distributed among 80 Shahid Beheshti University female students at the master level. The questionnaires include 18 questions which are mainly to diagnose the cultural elements which might hinder the learning process, and to propose solutions on its basis. Topics include five main domains as follows: 1) the usage of both Iranian and English cultural based factors; 2) learners' faithfulness to Iranian culture as a criterion in avoiding cultures' devastations by focusing on English culture; 3) religious and political beliefs; 4) the effect of globalization on English language learning; and 5) avoiding strategies in using topics regarding taboo vocabulary as cultural barriers.

Attention has been given to the reliability and validity matters, as the aspects of precision of the measurement via questionnaires here; though to achieve higher precision 80 subjects were considered, the declared answers of who to the questionnaires were calculated in the research. The reliability measure was quantified by the form of retest reliability; i.e. its reproducibility by measuring the same subjects twice with a gap of ten days between tests. Questionnaire's internal validity, in reflecting the concept of measuring the cultural barriers, has also been checked with pioneers in the subject.

\section{Participants}

A questionnaire was distributed among 80 (females) Shahid Beheshti University students (aged between 20 to 30 years). It contained 18 questions asking the participants to express their opinion in regard to the effect of culture in English language learning and the cultural elements which might hinder their learning process. In conducting the research, only females were considered due to the availability matter; whose declarations in completing the questionnaires have been considered here.

\section{Data Analysis}

The task of analyzing the survey data is performed via describing how responses are distributed among the 5 categories for each question. The frequency tables of counts and percentages are calculated and presented below (in 5 tables). The analysis describes the relationships between the items in the survey. Obviously, the selection of the variables included in the tabular analysis is based on the research findings.

The questionnaires include 18 questions asking about 5 different topics that are used for diagnosing the elements hindering the learning process of English as a second language in Iran.

For instance, table 1 includes items asking respondents to rate how the usage of both Iranian and English cultural based factors may be useful. To organize this data the items are rank-ordered by the percent of responses who say an item is totally agreed / partially agreed / neither agreed nor disagreed / partially disagreed / totally disagreed. In this way, information about a number of items can be presented in the tables. Note that the same pattern has been used to highlight the percentage of the measured responses for the other 4 group of items. In sum, organizing the data in this way facilitates comparison among the types of items of the survey, and is also useful for summarizing data for further evaluations.

Table 1

Table 2

Table 3

Table 4

Table 5

Based on the rankings above, the usage of both Iranian and English culture could be interpreted as the top 
priority needs in the community being studied $(41.25 \%$ agree). It also shows that barriers like taboo words, political relations (31\% partially agree) and religious factors (31.5\% disagreed) are partially effective on ELT.

In accordance, the information from tables show that students partially agreed with the first category $(41.25 \%)$ and believed using both Iranian and English culture in discussion and text books could facilitate the learning. The answers to the second category, learners' faithfulness to Iranian culture, showed that students were partially disagreeing with the question of this category (45\%). The result of third category, religious and political beliefs, indicates that students were partially disagreeing with the question of this category $(31.5 \%)$ except one of the questions which was about positive political relation with English spoken countries (31\% partially agree). The fourth category, in relation to the effect of globalization on ELT and the result showed partial disagreement of students with this category (42.66\%). In the fifth and the last category which was about taboo words, $31.5 \%$ of students had no opinion and neither agreed nor disagreed with it, $27.50 \%$ partially disagreed and $27.75 \%$ partially agreed.

Consequently in analyzing the categories and items in general terms the results illustrate that Iranian students could have a better learning when both Iranian and English culture were used in English text teachings and also that barriers as taboo words or political and religious relations have partial effectiveness on ELT. That is incorporating these items into Islamic teachings may help achieving the best results in ELT in Iran.

\section{Conclusions}

With the aim of diagnosing the elements hindering the learning process of English as a second language in Iran, typically known as cultural barriers, the present research throws lights on their positive and negative impacts on ELT. For the purpose of the research percentages are used to express how the five main domains under consideration and the included matters are relative to one another. The statistical analyses of the questionnaires prepared for the research explores the effect of the usage of social factors, religious matters and taboo words as cultural dimensions on ELT; i.e. diagnosing the matters hindering or fostering the ELT learning process in the community being studied.

The partial effect of each domain on hindering the learning process is calculated on the basis of the questionnaire results. The results highlight the main criteria in ELT included under the broad term of cultural barriers and its implications on overcoming the desired outcomes in the teaching/learning process in Iran.

It illustrates that English learning may be more effectively processed for Iranian students if both Iranian and English culture will be used ( $41.25 \%$ agree). It also shows that barriers like taboo word (indifferent stance) or political relations ( $31 \%$ partially agree) and religious factors (31.5\% disagreed) are partially effective on ELT.

Consequently, taking the research findings into consideration and incorporating the notified items together with Islamic teachings and making its acquaintance with L2 language culture may help achieving the best results and solving learners' problems in ELT classrooms in Iran.

\section{References}

Alptek, Cem. (1993). Target-language culture in EFL materials. ELT Journal, 47(2): 136-143.

Byram, M. \& Esarte-Sarries, V. (1991). Investigating Cultural Studies in Foreign Language Teaching. Clevedon: Multilingual Matters.

Byram, M. S. \& K. Risager. (1999). Language Teachers, Politics and Cultures. Multilingual Matters Ltd.

Byram, M. S. (1989). Cultural Studies in Foreign Language Education. Clevedon: Multilingual Matters.

Chen, Huiyuan. (1999). Theoretically probe into causes of language fossilization. Foreign Language Teaching and Research, No. 3.

DiMaggio, Paul. (1997). Culture and Cognition. Annual Review of Sociology, Vol. 23, 263-287.

Folds, Ralph. (1989). A Socio-Cultural Approach to the Bilingual Curriculum in Central Australian School. Curriculum Inquiry, No. 1, Spring.

Gardner, R. C. \& Lambert, W. E. (1972). Attitudes and motivation in second-language learning. Rowley, MA: Newbury House Publishers.

Gardner, R. C., \& Lambert, W. E. (1959). Motivational variables in second language acquisition. Canadian Journal of Psychology, 13, 266-272.

Harris, S. (1982). Bilingual education in the Northern Territory: A sharp tool easily blunted. Australian review of applied linguistics, 5.1.25-59. 
Heller, M. (1987). The role of language in the formation of ethnic identity. In J. S. Phinney \& M. J. Rotheram (Eds.), Children's ethnic socialization: Pluralism and development (pp. 180-200). Newbury Park, CA: Sage.

Hinenoya, kimiko \& Gatbonton, Elizabeth. (2000). Ethnocentrism, Cultural Traits, Beliefs, and English Proficiency: A Japanese Sample. The Modern Language Journal, No. 2, Summer.

Huang, Qian. (2009). Probe into the Internal Mechanism of Interlanguage Fossilization. English Language Teaching, No. 2, June.

Kniffka, Hannes. (2001). Indigenous Grammar Across Cultures. Peter Lang Publishing.

Kress, Gunther. (1993). Participation and difference: the role of language in producing a culture of innovation. In A. Luke \& P. Gilbert (Eds.), Literacy in Contexts: Australian Perspectives and Issues. Sydney: Allen \& Unwin.

Nguyen, Thi Mai Hoa. (2007). Developing EFL learners' intercultural communicative competence: A gap to be filled? Asian EFL Journal, Volume 21.

Riona. (2007). Cultural Barriers of Language Teaching: A Case Study of Classroom Cultural Obstacle. Power point presentation. Instructor: Chin-Lin Lee.

Salam, Sultana A. (2007). Cultural Barriers in Health Care Delivery to the Muslim Women of the USA. Paper presented at the Women's Health Conferrence.

Vorih, L. and Rosier, P. (1978). Rock Point Community School: An Example of a Navajo-English Bilingual Elementary School Program. TESOL Quarterly, 12, 3, pp. 263-269.

Table 1. Usage of both Iranian and English cultural based factors

\begin{tabular}{|l|l|l|l|l|l|}
\hline Questions & $\begin{array}{l}\text { Totally } \\
\text { Agree }\end{array}$ & $\begin{array}{l}\text { Partially } \\
\text { Agree }\end{array}$ & $\begin{array}{l}\text { Neither } \\
\text { Agree } \\
\text { nor Disagree }\end{array}$ & $\begin{array}{l}\text { Partially } \\
\text { Disagree }\end{array}$ & $\begin{array}{l}\text { Totally } \\
\text { Disagree }\end{array}$ \\
\hline $\begin{array}{l}\text { 1- Using Iranian culturally related topics in } \\
\text { discussions would lead to a better understanding of } \\
\text { ELT texts. }\end{array}$ & $29 \%$ & $41 \%$ & $6 \%$ & $24 \%$ & 0 \\
\hline $\begin{array}{l}\text { 2- Knowing the culture of English speaking countries } \\
\text { would facilitate the learning process. }\end{array}$ & $59 \%$ & $24 \%$ & $12 \%$ & $6 \%$ & 0 \\
\hline $\begin{array}{l}\text { 3- By keeping learners free in choosing the } \\
\text { discussion topics, Iranian learners would select } \\
\text { subjects based on their culture. }\end{array}$ & $6 \%$ & $76 \%$ & $12 \%$ & $6 \%$ & 0 \\
\hline $\begin{array}{l}\text { 4- Preparing the syllabus on the basis of both Iranian } \\
\text { and English culture will be helpful in understanding } \\
\text { the text. }\end{array}$ & $47 \%$ & $24 \%$ & $25 \%$ & $4 \%$ & 0 \\
\hline
\end{tabular}

Table 2. Faithfulness to Iranian culture

\begin{tabular}{|l|l|l|l|l|l|}
\hline Questions & $\begin{array}{l}\text { Totally } \\
\text { Agree }\end{array}$ & $\begin{array}{l}\text { Partially } \\
\text { Agree }\end{array}$ & $\begin{array}{l}\text { Neither } \\
\text { Agree nor } \\
\text { Disagree }\end{array}$ & $\begin{array}{l}\text { Partially } \\
\text { Disagree }\end{array}$ & $\begin{array}{l}\text { Totally } \\
\text { Disagree }\end{array}$ \\
\hline $\begin{array}{l}\text { 5- Learners' fear of losing Iranian traditions and values } \\
\text { has negative effect on ELT. }\end{array}$ & 0 & $12 \%$ & $24 \%$ & $47 \%$ & $17 \%$ \\
\hline 6- Tribe's prejudices would hinder the learning process. & $6 \%$ & 0 & $29 \% \%$ & $53 \%$ & $12 \%$ \\
\hline $\begin{array}{l}\text { 7- Learners faithfulness to the Iranian culture and } \\
\text { Islamic believes would limit learners not to choose } \\
\text { subjects such as alcoholism, premarital relationship... in } \\
\text { their discussion }\end{array}$ & $12 \%$ & 0 & $29 \%$ & $35 \%$ & $24 \%$ \\
\hline
\end{tabular}


Table 3. Religious and political beliefs

\begin{tabular}{|c|c|c|c|c|c|}
\hline Questions & $\begin{array}{l}\text { Totally } \\
\text { Agree }\end{array}$ & $\begin{array}{l}\text { Partially } \\
\text { Agree }\end{array}$ & $\begin{array}{l}\text { Neither } \\
\text { Agree nor } \\
\text { Disagree }\end{array}$ & $\begin{array}{l}\text { Partially } \\
\text { Disagree }\end{array}$ & $\begin{array}{l}\text { Totally } \\
\text { Disagree }\end{array}$ \\
\hline $\begin{array}{l}\text { 8- Using Islamic related topics rather than other } \\
\text { religions (such as Christian) would lead to a } \\
\text { better understanding of the texts. }\end{array}$ & $6 \%$ & $24 \%$ & 0 & $47 \%$ & $17 \%$ \\
\hline $\begin{array}{l}\text { 9- Broadcasting of the Iranian television in } \\
\text { regard to England or America as imperialistic } \\
\text { countries discourage Iranian learners to learn } \\
\text { English. }\end{array}$ & $24 \%$ & $18 \%$ & $15 \%$ & $35 \%$ & $8 \%$ \\
\hline $\begin{array}{l}\text { 10- Iran's political relation to English speaking } \\
\text { countries has positive effect on ELT. }\end{array}$ & $29 \%$ & $31 \%$ & $18 \%$ & $9 \%$ & $6 \%$ \\
\hline $\begin{array}{l}\text { 11- The boycott of English speaking countries on } \\
\text { Iran and Iran's neighboring countries with the } \\
\text { same religion (Iraq, Afghanistan, Pakistan...) has } \\
\text { negative impact on English learning process. }\end{array}$ & $24 \%$ & $12 \%$ & 0 & $35 \%$ & $29 \%$ \\
\hline
\end{tabular}

Table 4. The effect of globalization on ELT

\begin{tabular}{|l|l|l|l|l|l|}
\hline Questions & $\begin{array}{l}\text { Totally } \\
\text { Agree } \\
\text { Agree }\end{array}$ & $\begin{array}{l}\text { Partially } \\
\text { Agree nor } \\
\text { Disagree }\end{array}$ & $\begin{array}{l}\text { Partially } \\
\text { Disagree }\end{array}$ & $\begin{array}{l}\text { Totally } \\
\text { Disagree }\end{array}$ \\
\hline $\begin{array}{l}\text { 12- Learners' concept of globalization as cultural } \\
\text { dominance of a country over others has negative } \\
\text { effect on ELT. }\end{array}$ & $18 \%$ & $12 \%$ & $5 \%$ & $40 \%$ & $25 \%$ \\
\hline $\begin{array}{l}\text { 13- Learners' concept of globalization as vanishing } \\
\text { of Iran's old culture and traditional believes has } \\
\text { negative effect on ELT. }\end{array}$ & 0 & $4 \%$ & $29 \%$ & $47 \%$ & $20 \%$ \\
\hline $\begin{array}{l}\text { 14- Globalization leads to an imperialistic view and } \\
\text { political dominance of English spoken countries } \\
\text { over other countries. }\end{array}$ & 0 & $6 \%$ & $24 \%$ & $41 \%$ & $29 \%$ \\
\hline
\end{tabular}

Table 5. Taboo words as cultural barriers

\begin{tabular}{|l|l|l|l|l|l|}
\hline Questions & $\begin{array}{l}\text { Totally } \\
\text { Agree }\end{array}$ & $\begin{array}{l}\text { Partially } \\
\text { Agree } \\
\text { Agree nor } \\
\text { Disagree }\end{array}$ & $\begin{array}{l}\text { Partially } \\
\text { Disagree }\end{array}$ & $\begin{array}{l}\text { Totally } \\
\text { Disagree }\end{array}$ \\
\hline $\begin{array}{l}\text { 15- Taboo words cause perception gap for Iranian } \\
\text { learners. }\end{array}$ & $1 \%$ & $28 \%$ & $23 \%$ & $40 \%$ & $8 \%$ \\
\hline $\begin{array}{l}\text { 16- Iranian learners refuse using English words which } \\
\text { are homophones to taboo words in their language. }\end{array}$ & $2 \%$ & $4 \%$ & $48 \%$ & $21 \%$ & $25 \%$ \\
\hline $\begin{array}{l}\text { 17- Avoiding using subjects related to taboo words } \\
\text { would help learners to preserve their culture and } \\
\text { religion. }\end{array}$ & 0 & $36 \%$ & $40 \%$ & $18 \%$ & $6 \%$ \\
\hline $\begin{array}{l}\text { 18- Iranian learners avoid using subjects related to } \\
\text { taboo words. }\end{array}$ & $29 \%$ & $35 \%$ & $15 \%$ & $20 \%$ & $11 \%$ \\
\hline
\end{tabular}

